\title{
The Effect of Long-Term Ageing on the Degradation of the Microstructure the Inconel 740h Alloy
}

\author{
M. SROKA ${ }^{a, *}$, A. Zieliński ${ }^{b}$, A. Śliwa ${ }^{a}$, M. NABIAŁEK $^{c}$, Z. KANiA-PifCZYK $^{b}$ \\ AND I. VASKOVÁ ${ }^{d}$ \\ ${ }^{a}$ Institute of Engineering Materials and Biomaterials, Silesian University of Technology, \\ S. Konarskiego 18A, 44-100 Gliwice, Poland \\ ${ }^{b}$ Institute for Ferrous Metallurgy, K. Miarki 12-14, 44-100 Gliwice, Poland \\ ${ }^{c}$ Institute of Physics, Faculty of Production Engineering and Materials Technology, \\ Częstochowa University of Technology, al. Armii Krajowej 19, 42-200 Częstochowa, Poland \\ ${ }^{d}$ Faculty of Materials, Metallurgy and Recycling, Technical University of Kosice, \\ Letná 9, 04200 Košice, Slovak Republic
}

(Received August 22, 2019; revised version November 19, 2019; in final form December 10, 2019)

The Inconel $740 \mathrm{H}$ alloy is used in the construction of pressure components of ultra-supercritical operating parameters. The paper presents the results of microstructure analysis after 1000 and $10000 \mathrm{~h}$ ageing at 700 and $750^{\circ} \mathrm{C}$. Microstructure studies were made using scanning and transmission electron microscopy. Identification of precipitations was made using X-ray analysis of phase composition. The influence of ageing time on changes in microstructure and the precipitation process of the tested alloy were described. Presented research results are a material characteristic of new generation materials, which are used in the design of elements of pressure parts of boilers and diagnostics work during operation.

DOI: 10.12693/APhysPolA.137.355

PACS/topics: Inconel 740H, microstructure, precipitations, annealing, austenite

\section{Introduction}

The power industry in Poland is $88 \%$ based on solid fuel combustion and from the end of the last century is continuously being modernised through the construction of new steam boilers and by improving the operation of power units so far. This is caused mainly due to the concern for the country's energy security and the requirements of the broadly defined environmental protection. In addition, this development stimulates the fact that the growth of alternative energy technologies, which has been promoted for years, indicates that they will not be yet, in a long time, the primary source of energy not only in Poland but also in the world.

Therefore, the above information clearly indicates that work on the development of new materials for the hightemperature power industry and related technologies for the manufacture of finished components cannot be neglected [1-4]. The directions of the national power industry development are also forced by the geopolitical conditions of the country. Appropriate development directions are the modernization of existing units (mainly with the capacity of 200 MW created in the years 1960-1970) and construction of modern power units for over- and transient-critical parameters $[5,6]$. The most effective

*corresponding author; e-mail: marek.sroka@polsl.pl way to improve efficiency and reduce harmful emissions for today's carbon-fueled blocks is to raise of thermodynamic parameters values of the water-steam circuit [7-10].

Construction of supercritical boilers dates back to the 1950s. This was the case in the US, where the first prototype blocks were created at the Eddystone power plant, owned by Philadelphia Electric Co. The blocks with parameters $30 \mathrm{MPa} / 649 / 566^{\circ} \mathrm{C}$ were also developed in Ukraine [11-15]. At that time basic austenitic steels and technologies were used, which unfortunately did not meet the quality requirements. The lack of experience contributed to the development of technological errors. On the other hand, little knowledge of austenitic steels and alloys and their way of operation caused considerable operational issues, which led to the low availability of these blocks.

In the middle of nineties, a return to the construction of supercritical blocks was made, which contributed to the works to be carried out on the application of new austenitic alloy steels and alloys. The Inconel $740 \mathrm{H}$ is a derivative of the Nimonic 263 alloy, which in its initial development led to the Inconel 740 alloy, followed by the modernization of the chemical composition (optimisation of the concentration between $\mathrm{Nb}, \mathrm{Ti}, \mathrm{Al}$ and $\mathrm{Bi}$, Si reduction) to Inconel $740 \mathrm{H}$ [16-20].

The alloys with austenitic structure, compared to the ferritic and martensitic steels used in the power industry till now, are characterised by different mechanical and physical properties. They show higher high-temperature 
creep resistance and heat resistance and worse physical properties, i.e., low thermal conductivity or high coefficient of linear expansion [5].

For materials used in the construction of steam boilers, the requirement is only adequate creep strength but also high mechanical properties, both at room and elevated temperatures. The process of changes in the functional properties of these materials, and thus changes in their microstructure, describe the material characteristics that, in connection with the methods of assessing their exhaustion, are used to allow them to continue to work safely in both computational and off-set working hours [21-26].

\section{Material for investigation}

The tested material was the Inconel $740 \mathrm{H}$ (NiCr25Co20TiAlNb) nickel superalloy, whose chemical composition concerning the requirements of the standard is shown in Table I. The material as delivered was subjected to supersaturation at $1150^{\circ} \mathrm{C}$ for $0.5 \mathrm{~h}$ and ageing at $750^{\circ} \mathrm{C}$ for $0.5 \mathrm{~h}$. This alloy is used for boiler components with ultracritical steam parameters (temperature $700-760^{\circ} \mathrm{C}$, pressure about $35 \mathrm{MPa}$ ). The Inconel $740 \mathrm{H}$ has a high creep resistance with respect to other nickel alloys of 210 and $120 \mathrm{MPa}$ at 700 and $750^{\circ} \mathrm{C}$, respectively for up to $100,000 \mathrm{~h}$. This is primarily due to the molybdenum and cobalt solution strengthening effect and $\mathrm{M}_{23} \mathrm{C}_{6}$ carbide separation process, and the intermetallic phase $\gamma^{\prime} \mathrm{Ni} 3(\mathrm{Ti}, \mathrm{Al}, \mathrm{Nb})$ precipitated at $700 \div 800^{\circ} \mathrm{C}$. High chromium content makes this alloy very highly resistant to high-temperature corrosion and steam oxidation. The value of creep strength is a good recommendation for use in boilers with supercritical work parameters. Samples were taken from pipe sections with dimensions $\varphi 31.8 \times 6.3 \mathrm{~mm}^{2}$.

TABLE I

Chemical composition of investigated alloy (in wt\%).

\begin{tabular}{c|c|c}
\hline \hline Element & $\begin{array}{c}\text { Tested } \\
\text { material }\end{array}$ & $\begin{array}{c}\text { Acc. to } \\
\text { UNS N07740 }\end{array}$ \\
\hline $\mathrm{C}$ & 0.03 & $0.005-0.08$ \\
$\mathrm{Mn}$ & 0.10 & $\leq 1.0$ \\
$\mathrm{Cr}$ & 24.37 & $23.50-25.50$ \\
$\mathrm{Ti}$ & 0.87 & $0.50-2.50$ \\
$\mathrm{Mo}$ & 1.56 & $\leq 2.0$ \\
$\mathrm{Co}$ & 20.67 & $15.00-22.00$ \\
$\mathrm{Nb}$ & 0.65 & $0.50-2.50$ \\
$\mathrm{Al}$ & 1.44 & $0.20-2.00$ \\
$\mathrm{Ni}$ & bal. & bal.
\end{tabular}

\section{Methodology}

The observation of the Inconel $740 \mathrm{H}$ alloy microstructure was carried out using a light microscope, OLYMPUS DSX500i (LM), scanning electron microscope, Inspect F
(SEM), on conventional prepared electrolytic etched metallographic microsections and TITAN 80-300 (TEM) electron microscopy using thin films. The analysis of the precipitation processes was carried out by X-ray analysis of carbide isolates and thin films using selective electron diffraction. The quantitative analysis of the precipitates was performed using the image analysis system NIKON EPIPHOT200 \& LUCIA G v.5.03. Using the image scale marker, the image analysis system was calibrated. Calibration factor: 1 pixel $=0.040 \mu \mathrm{m}$. The above tests were performed on the material in delivery state and after long-term ageing for 1000 and 10,000 h at 700 and $750{ }^{\circ} \mathrm{C}$.

\section{Results}

The microstructure of the Inconel $740 \mathrm{H}$ alloy in the delivery state observed in the scanning electron microscope is shown in Fig. 1. The tested material is characterised by an austenitic matrix with numerous annealing twins and single primary precipitates of varying sizes distributed within thick grains with an average diameter of about $100 \mu \mathrm{m}$ (close to ASTM size cards).
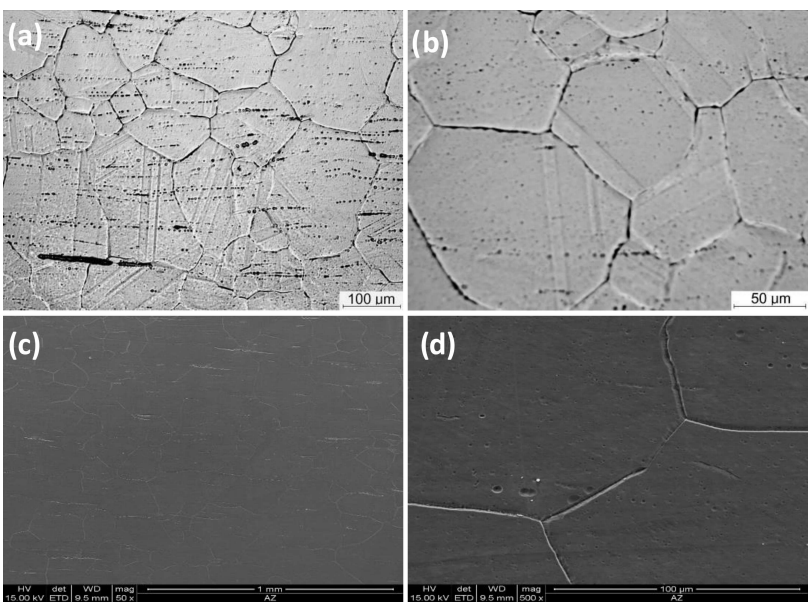

Fig. 1. Microstructure of the Inconel $740 \mathrm{H}$ alloy in delivery state: $(a, b)$ LM, (c, d) SEM.

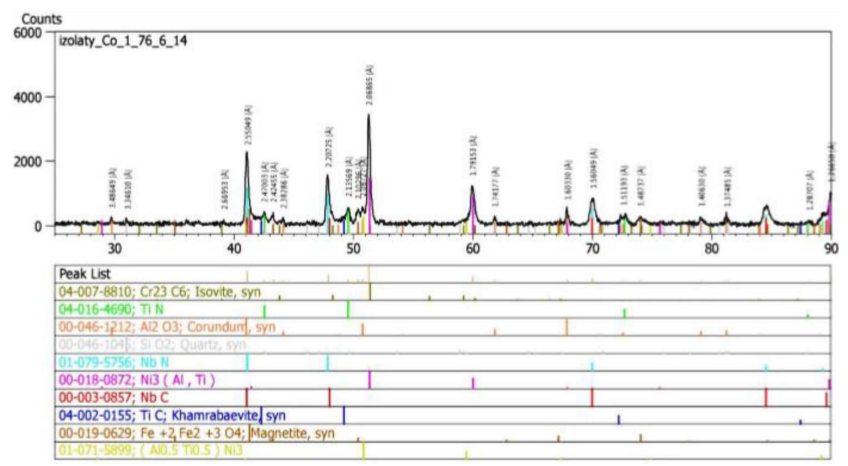

Fig. 2. X-ray diffraction pattern of Inconel $740 \mathrm{H}$ alloy isolate - delivery state. 

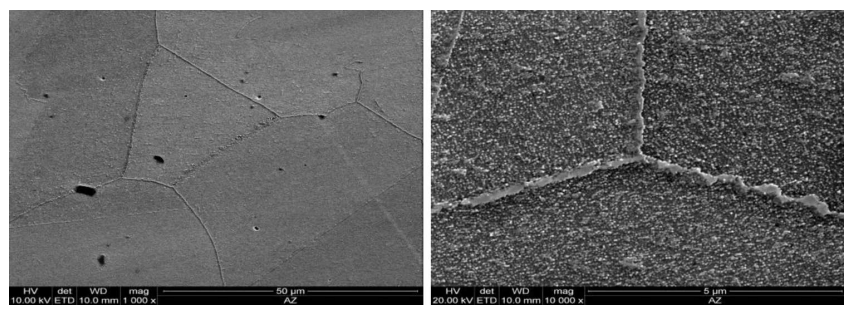

Fig. 3. Microstructure of Inconel $740 \mathrm{H}$ alloy after ageing at $700^{\circ} \mathrm{C}$ for $1000 \mathrm{~h}$, SEM.
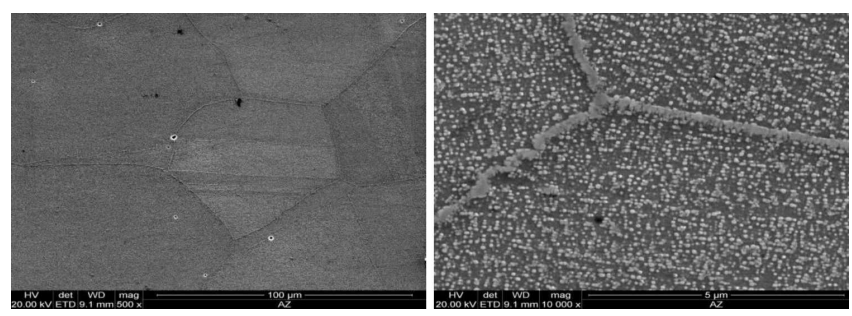

Fig. 4. As in Fig. 3, but at $750^{\circ} \mathrm{C}$.
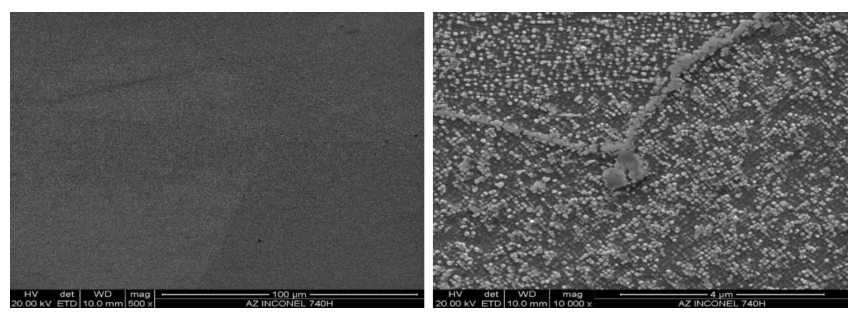

Fig. 5. As in Fig. 3, but at $700{ }^{\circ} \mathrm{C}$ and for $10,000 \mathrm{~h}$.
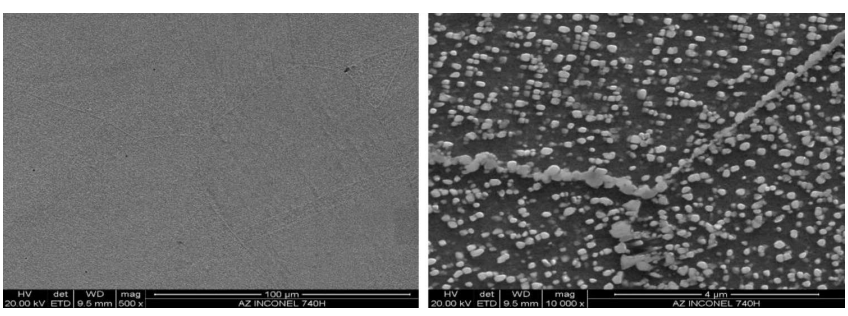

Fig. 6. As in Fig. 3, but at $750{ }^{\circ} \mathrm{C}$ and for $10,000 \mathrm{~h}$.

The X-ray analysis of the phase composition of the precipitates showed the presence of carbides, niobium, and titanium nitride $\mathrm{M}(\mathrm{C}, \mathrm{N})$, carbide $\mathrm{Cr}_{23} \mathrm{C}_{6}$, and $\gamma^{\prime}$ phase (Fig. 2).

The ageing of the Inconel $740 \mathrm{H}$ alloy at 700 and $750{ }^{\circ} \mathrm{C}$ and the time of up to $10,000 \mathrm{~h}$ results in the development of precipitation processes, as well as the change in morphology coherent with $\gamma^{\prime}$ matrix and $\mathrm{M}_{23} \mathrm{C}_{6}$ carbide, which the microstructural observation confirms (Figs. 3-6). Along with the ageing time elongation, the number and size of $\mathrm{Cr}_{23} \mathrm{C}_{6}$ carbides increased on the austenite grains and twins with evenly distributed normal precipitations of $\gamma^{\prime}$ phase within the austenite grains and in the immediate neighbourhood of carbides at the grain boundaries.
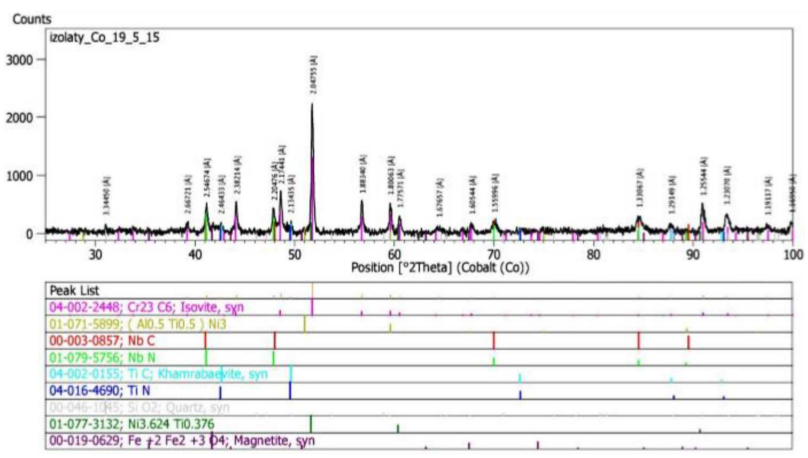

Fig. 7. X-ray diffraction pattern of Inconel $740 \mathrm{H}$ alloy isolate — ageing $1000 \mathrm{~h} / 700{ }^{\circ} \mathrm{C}$.

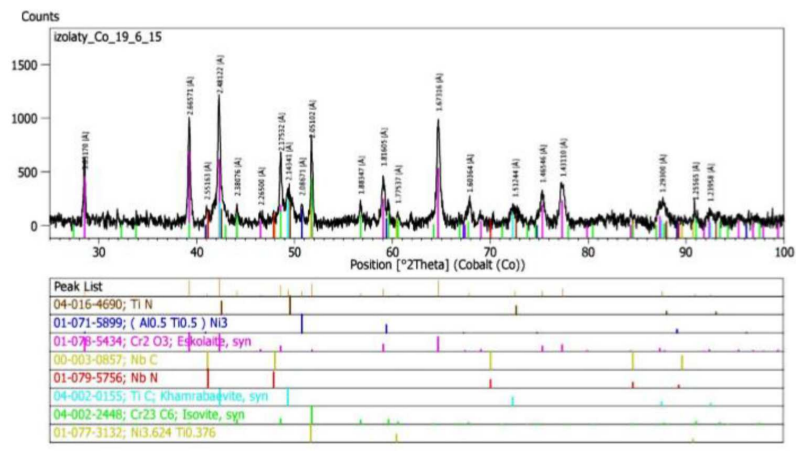

Fig. 8. X-ray diffraction pattern of Inconel $740 \mathrm{H}$ alloy isolate - ageing $1000 \mathrm{~h} / 750^{\circ} \mathrm{C}$.

The X-ray analysis of the precipitations phase composition of ageing after $1000 \mathrm{~h}$ at 700 and $750^{\circ} \mathrm{C}$ showed that after ageing at $700^{\circ} \mathrm{C}$ and $1000 \mathrm{~h}$, the main phase was $\mathrm{Cr}_{23} \mathrm{C}_{6}$ carbide and in lesser extent' phase (Fig. 7). Increasing the ageing temperature to $750^{\circ} \mathrm{C}$ significantly intensifies the precipitation process phase $\gamma^{\prime}$, which after $1000 \mathrm{~h}$ is the phase with the highest percentage (Fig. 8). The above studies are confirmed by the microstructural observation and identification of precipitations carried out by transmission electron microscopy. It showed in the studied material after ageing at $750{ }^{\circ} \mathrm{C}$ and $1000 \mathrm{~h}$ the appearance of the $\gamma^{\prime}$ phase separation (Fig. 9) of carbides $\mathrm{Cr}_{23} \mathrm{C}_{6}$ (Fig. 10) and nitride carbides $\mathrm{Ti}_{2}$ (C,N) (Fig. 11). The chemical composition of the identified precipitations is summarised in Table II.

The quantitative analysis of $\gamma^{\prime}$ phase precipitation (Fig. 12) showed that the average diameter of this phase after ageing for $1000 \mathrm{~h}$ at 700 and $750^{\circ} \mathrm{C}$ was 29 and $76 \mathrm{~nm}$, respectively, and after $10,000 \mathrm{~h}$ at 700 and $750{ }^{\circ} \mathrm{C}$ was 72 and $135 \mathrm{~nm}$, respectively. The similar results for a superalloy Inconel $740 \mathrm{H}$ were presented in [27, 28]. The average $\gamma^{\prime}$ phase precipitation size for superalloy $740 \mathrm{H}$ fabricated by electron beam smelting was (30 nm) and $42 \mathrm{~nm}$ for Inconel $740 \mathrm{H}$ prepared by the traditional vacuum induction melting plus vacuum arc remelting. Most of the phases were observed both in the delivery and creep tested alloy $740 \mathrm{H}$ has been described in an analogous investigation of aged alloy $740 \mathrm{H}[27,29-31]$. 

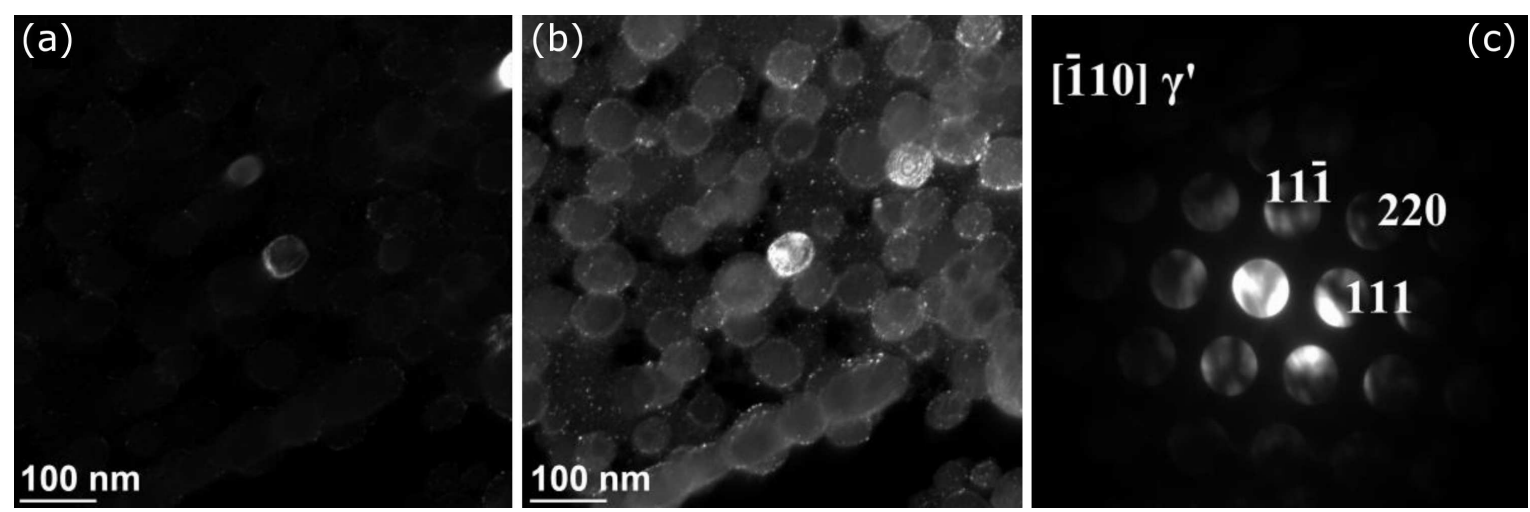

Fig. 9. Precipitation of $\gamma^{\prime}$ phase in the Inconel $740 \mathrm{H}$ alloy after ageing at $750{ }^{\circ} \mathrm{C}$ and $1000 \mathrm{~h}$ : (a) bright field, (b) dark field, (c) dissolved diffraction pattern, TEM.
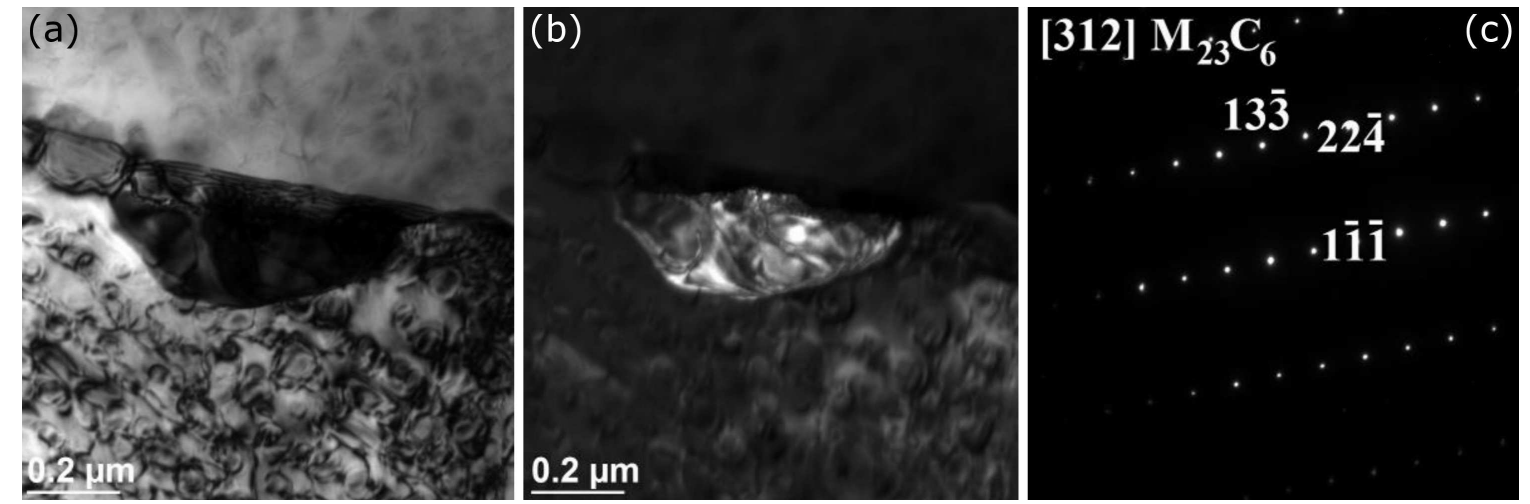

Fig. 10. As in Fig. 9, but for precipitation of $\mathrm{Cr}_{23} \mathrm{C}_{6}$ carbide.
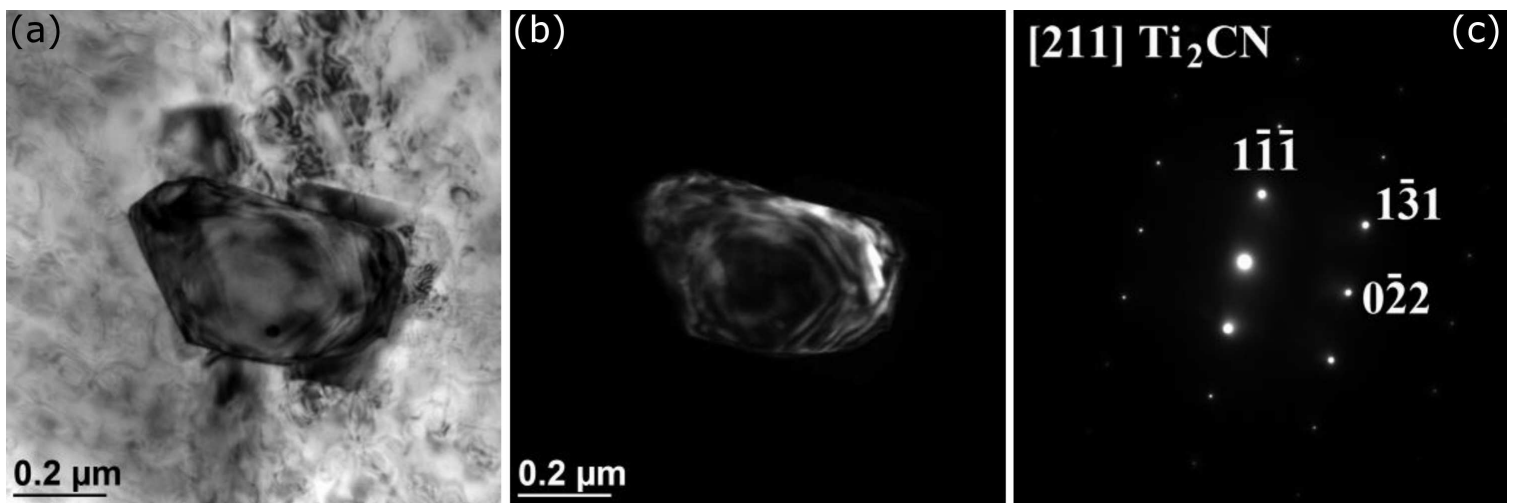

Fig. 11. As in Fig. 9, but for precipitation of carbide $\mathrm{Ti}_{2}$.

TABLE II

Analysis of chemical composition of identified precipitations in Inconel $740 \mathrm{H}$ alloy after $1000 \mathrm{~h}$ of ageing at $750{ }^{\circ} \mathrm{C}$.

\begin{tabular}{l|c|c|c|c|c|c|c|c|c}
\hline \hline \multirow{2}{*}{$\begin{array}{c}\text { Analysed } \\
\text { precipitation }\end{array}$} & \multicolumn{10}{c}{ Chemical composition [wt\%] } \\
\cline { 2 - 10 } & $\mathrm{Al}$ & $\mathrm{Ti}$ & $\mathrm{Cr}$ & $\mathrm{Co}$ & $\mathrm{Ni}$ & $\mathrm{Mo}$ & $\mathrm{Nb}$ & $\mathrm{C}$ & $\mathrm{N}$ \\
\hline faza $\gamma^{\prime}$ & 4.03 & 6.29 & 1.89 & 4.92 & 75.54 & - & 7.31 & - & - \\
$\mathrm{Cr}_{23} \mathrm{C}_{6}$ & 0.46 & 0.61 & 67.34 & 8.00 & 19.14 & 0.88 & 0.73 & 2.81 & - \\
$\mathrm{Ti}_{2}(\mathrm{C}, \mathrm{N})$ & - & 19.08 & 0.70 & 0.19 & 1.57 & - & 68.26 & 7.31 & 2.86
\end{tabular}




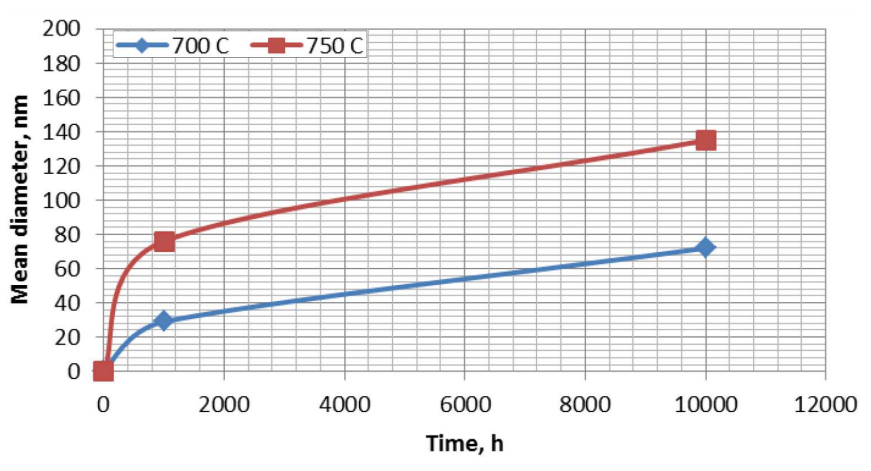

Fig. 12. Change of mean $\gamma^{\prime}$ phase diameter depending on ageing time and temperature.

\section{Summary}

The Inconel $740 \mathrm{H}$ alloy due to the high creep resistance at elevated temperatures and very good hightemperature corrosion resistance and steam oxidation is recommended for long-term operation in creep conditions up to $700-750^{\circ} \mathrm{C}$.

At the starting state, the tested alloy is characterised by an austenitic microstructure with visible annealed twins and an average grain diameter of about $100 \mu \mathrm{m}$. The X-ray analysis of the phase composition of the precipitates showed the occurrence of the carbide and niobium and titanium nitride $\mathrm{M}(\mathrm{C}, \mathrm{N})$, carbide $\mathrm{Cr}_{23} \mathrm{C}_{6}$, and $\gamma^{\prime}$ phase in the delivery state of the tested alloy.

The ageing tests conducted at $700-750^{\circ} \mathrm{C}$ for up to $10,000 \mathrm{~h}$ revealed significant changes in the microstructure, mainly due to the tendency to form a $\gamma^{\prime}$ phase and the unfavourable morphology of the precipitates mainly $\mathrm{Cr}_{23} \mathrm{C}_{6}$ carbides which form intermittent and continuous carbide systems within the grain boundaries and annealing twins (Figs. 3-6). These systems already form in the early stages of ageing at $700^{\circ} \mathrm{C}$ for up to $1000 \mathrm{~h}$ when thermally activated processes cause chromium segregation in micro-areas adjacent to the grain boundaries and then the formation of continuous, reticulated carbide systems.

The measurement of the average diameter of the $\gamma^{\prime}$ phase precipitation for samples aged at two temperatures of 700 and $750^{\circ} \mathrm{C}$ and 1000 and $10,000 \mathrm{~h}$ indicates that raising the ageing temperature from 700 to $750{ }^{\circ} \mathrm{C}$ contributes to a tenfold increase in $\gamma^{\prime}$ phase growth in time up to $10,000 \mathrm{~h}$. As part of this work ageing tests up to 20,000 and $50,000 \mathrm{~h}$, were also carried out, the results of which are presented after reaching the assumed ageing time.

\section{Acknowledgments}

This publication was co-financed within the framework of the statutory financial grant supported by the Faculty of Mechanical Engineering of the Silesian University of Technology. The results in this publication were obtained as a part of Research co-financed by the National Science Centre under contract 2011/01/D/ST8/07219, project: "Creep test application to model lifetime of materials for modern power generation industry".

\section{References}

[1] K. Wojsyk, G. Golański, J. Jasek, J. Słania, A. Zieliński, P. Urbańczyk, Arch. Metall. Mater. 61, 1425 (2016).

[2] A. Śliwa, W. Kwaśny, M. Sroka, R. Dziwis, Metalurgija 56, 422 (2017).

[3] M. Król, T. Tański, G. Matula, P. Snopiński, A.E. Tomiczek, Arch. Metall. Mater. 60, 2993 (2015).

[4] S. Ebied, A. Hamada, W. Borek, M. Gepreel, A. Chiba, Mater. Charact. 139, 176 (2018).

[5] A. Hernas, J. Dobrzański, J. Pasternak, S. Fudali, Characteristics of a New Generation of Materials for the Power Industry, Ed. A. Hernas, Publishing House of Silesian University of Technology, Gliwice 2015.

[6] M. Sroka, M. Nabiałek, M. Szota, A. Zieliński, Rev. Chim. 4, 737 (2017).

[7] L.W. Żukowska, A. Śliwa, A.J. Mikuł, M. Bonek, W. Kwaśny, M. Sroka, A.D. Pakuł, Arch. Metall. Mater. 61, 149 (2016).

[8] S.F. Di Martino, R.G. Faulkner, S.C. Hogg, S. Vujic, O. Tassa, Mater. Sci. Eng. A 619, 77 (2014).

[9] A. Hernas, Materials and Technologies for Construction of Supercritical Boilers and Waste Incinerators, Publishing House of Silesian University of Technology, Gliwice 2009.

[10] M. Sroka, A. Zieliński, A. Hernas, Z. Kania, R. Rozmus, T. Tański, A. Śliwa, Metalurgija 56, 333 (2017).

[11] R. Viswanathan, J.F. Henry, J. Tanzosh, G. Stanko, J. Shingledecker, B. Vitalis, R. Purgert, J. Mater. Eng. Perform. 14, 281 (2005).

[12] F. Abe, Sci. Technol. Adv. Mater. 9, 013002 (2008).

[13] M. Król, M. Staszuk, T. Mikuszewski, D. Kuc, J. Therm. Anal. Calorim. 134, 333 (2018).

[14] Y. Tanaka, I. Sato, J. Nucl. Mater. 417, 854 (2011).

[15] T. Tański, P. Snopiński, W. Borek, Mater. Manuf. Process. 32, 1368 (2017).

[16] S. Caminada, G. Cumino, L. Cipolla, D. Venditti, A. Di Gianfrancesco, Y. Minami, T. Ono, Int. J. Pres. Ves. Pip. 87, 336 (2010).

[17] C. Chi, H. Yu, X. Xie, Advanced Austenitic HeatResistant Steels for Ultra-Super-Critical (USC) Fossil Power Plants, InTech, Rijeka (Croatia) 2011.

[18] H. Igarashi, M. Semba, T. Yonemura, H. Hamaguchi, M. Okada, A. Yoshizawa, A. Iseda, in: Proc. 6th Int. Conf. Advances in Materials Technology for Fossil Power Plants, Santa Fe (NM), Eds. D. Gandy J. Shingledecker R. Viswanathan, ASM International, Materials Park (OH) 2011, p. 72.

[19] B. Peng, H. Zhang, J. Hong, J. Gao, H. Zhang, J. Li, Q. Wang, Mater. Sci. Eng. A 527, 4424 (2010). 
[20] P. Barnard, in: Materials for Ultra-Supercritical and Advanced Ultra-Supercritical Power Plants, Ed. A. Di Gianfrancesco, Woodhead Publ., Cambridge 2017, p. 99

[21] V. Sivakumar, J. Vijaeeswarri, J. Lakshmi Anna, Ind. Crop. Prod. 33, 116 (2011).

[22] T. Dudziak, V. Deodeshmukh, L. Backert, et al., Oxid. Met. 87, 139 (2017).

[23] M. Sroka, A. Zieliński, A.J. Mikuł, Arch. Metall. Mater. 61, 969 (2016).

[24] M. Król, J. Therm. Anal. Calorim. 133, 237 (2018).

[25] L.A. Dobrzański, W. Borek, J. Mazurkiewicz, Materialwiss. Werkst. 47, 428 (2016).
[26] K. Maile, Proced. Eng. 55, 214 (2013).

[27] S.Q. Zhao, X.S. Xie, G.D. Smith, Mater. Sci. Eng. A 355, 96 (2003).

[28] Y. Tan, X. You, Q. You, J. Li, S. Shi, P. Li, Mater. Charact. 114, 267 (2016).

[29] A. Zieliński, M. Sroka, T. Dudziak, Materials, 11, 2130 (2018)

[30] Y. Guo, T. Li, C. Wang, S. Hou, B. Wang, Trans. Nonferrous Met. Soc. China 26, 1598 (2016).

[31] C. Yan, L. Zhengdong, A. Godfrey, L. Wei, W. Yuqing, Mater. Sci. Eng. A 589, 153 (2014). 